日消外会誌 $12(3): 117 \sim 125,1979$ 年

原 著

食道疾患微細病変の診断に括ける食道連続撮影 100 例の検討

一早期食道癌, stage-O 癌の報告を含めて一

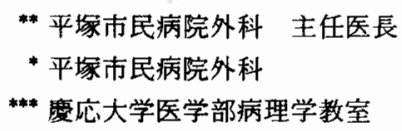

中山 隆市** 青木 明人* 岡芹 繁夫*

木村 嘉憲* 別所 隆* 鳥潟 親雄 ${ }^{* * *}$

張谷 健二***

\title{
A STUDY ON THE ONE HUNDRED CONSECUTIVE ESOPHAGOGRAM BY MEANS OF ELEMA-SCHÖNANDER APPARATUS FOR THE DIAGNOSIS OF MINUTE LESION OF THE ESOPHAGUS
}

-with the report of a case of stage-O carcinoma of the esophagus-

Ryuichi NAKAYAMA, M.D. et al.

Department of Surgery, Hiratsuka City Hospital, Kanagawa Pref.

食道の微細, 微小病変, 陥凹性, 表層拡大型病変のX線診断にはいまだ限界がある. 対策としてはバリ ウムの食道内通過時間の速さ，解剖学的な特殊性をよく理解し良い二重造影の撮影が重要である．曣下困 難等を主訴とし食道造影にて粗大病変の認められない症例を主な対象とし, 1973年来 Elema-Schönander 連続撮影装置を食道造影に応用し検討してきたが100例に達したのでその分析を行った。普遍的な食道撮 影の限界より，(1) 食道の部位別最適撮影条件の設定，(2) 食道 web などの比較的稀有例の描写，(3) また本法にて診断可能であった胃全摘後の食道 stage-0 癌および食道噴門接合部早期癌の各 1 例にも検討 を加究本法の臨床的有用性と意義につきのべた。

索引用語 食道連続撮影, 早期食道癌, stage-0 癌, 食道噴門接合部癌, Esophago-gastric junction.

はじめに

近年, 陥凹性むるいは表層拡大型病変を除き食道の微 細, 微小病変の猃断率はかなり向上し，また術前X線型 分類より予後の推定もかなり可能となってきている11. 現在, 食道癌手術の 5 生率は進行癌 st- III $13.7 \%$, stIV $\cdot 5.3 \%$ に較べ st -0 癌, いわゆる早期食道癌では約 60 \%と良好であるが，術前，食道癌X線猃断では $95 \%$ ，早 期癌の推定は62.3\%に可能とされている2).

本邦, 食道癌年間死亡, 約 7,200 例は胃癌の約 $1 / 10 \mathrm{~K}$ 相当するが3，早期胃癌報告例の多いのに較べ早期食道 癌の発見率はきわめて低く山形の初例報告)以来, 1978
年鍋谷の集計 ${ }^{2}$ までに101例が報告されているにすぎな い. その原因の 1 つとしてまず十分読影可能な良い食道 $\mathrm{X}$ 線造影の困難性と他方, 読影時病変の見落し等が考光 られるがこれらは即食道の解剖叔よび食道造影の特殊性 に起因することが少なくないように思われる。すなわち 造影㘊の食道通過時間の早さ,二重造影の困難性, 圧迫 触診不能の諸点が対策を必要とする問題点としてあげら れる(表 1，2)

今回，われわれは食道病変のX線診断改善の対策とし 乙秒間 6 枚撮影可能な連続撮影装置(Elema-Schönander) を食道造影飞応用し1973年来検討してきたが ${ }^{576)} ， 100$ 例 
表 1 食道の解剖

\begin{tabular}{|c|c|c|c|}
\hline & 走 & 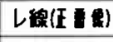 & 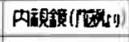 \\
\hline 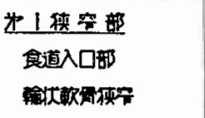 & 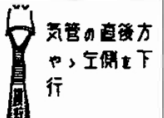 & *6 䤁 & $15 \mathrm{~cm}$ \\
\hline 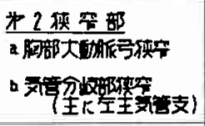 & 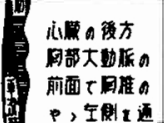 & 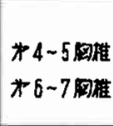 & $\begin{array}{l}22-25 \mathrm{~cm} \\
25-27 \mathrm{~cm}\end{array}$ \\
\hline 来了挍安部 & 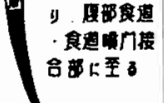 & 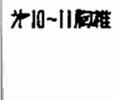 & $36-38 \mathrm{~cm}$ \\
\hline
\end{tabular}

表 2 食道造影の特殊性と対策

\begin{tabular}{|c|c|c|}
\hline 特 & 性 & 策 \\
\hline 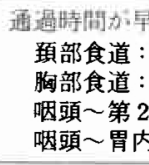 & $\begin{array}{l}\text { 平均 } 10.7 \mathrm{~cm} / \mathrm{sec} \\
5.0 \mathrm{~cm} / \mathrm{sec} . \\
\text { 狭窄部: } 1 / 4 \mathrm{sec} . \\
: 5 \mathrm{sec} .\end{array}$ & $\begin{array}{l}\text { 高浱度 Barium： } \\
\text { 100\%以上 } \\
\text { 蠕動抑制剤 } \\
\text { レ線映画 (High Speed) }\end{array}$ \\
\hline $\begin{array}{l}\text { 二重造影の困 } \\
\text { 第 } 1 \text { 次(第 }\end{array}$ & $\begin{array}{l}2 \text { 次) 蝶動波: } \\
\qquad 3 \sim 9 \mathrm{sec} .\end{array}$ & 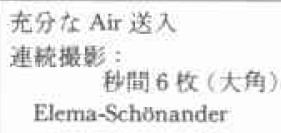 \\
\hline 王迫-触診才 & & $\begin{array}{l}\text { Riddervold (1971): } \\
\text { 譄卧位法 }\end{array}$ \\
\hline 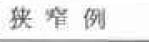 & & 低澧度 Barium \\
\hline $\begin{array}{l}\text { 胃手術後の } \\
\text { 造 }\end{array}$ & $\begin{array}{l}\text { 切除胃の胃泡縮小 } \\
\text { 胃全摘の胃泡欠損 }\end{array}$ & $\begin{array}{l}\text { 充分な Air 送入 } \\
\text { 発泡剂使用 }\end{array}$ \\
\hline
\end{tabular}

に達したので第 1 にその適用と条件につき，第 2 に一般 $\mathbf{X}$ 線撮影では困難之思われた病变の発見，診断に有用之 思われる成績をえたので症例の提示とともに併せここに 報告する．

\section{対象と方法}

対象は嚥下困難, 燕下異常, 嚥下痛等何らかの食道症 状をるって来院した90例と症状はないが集検などにて食 道の異常を指摘され来院した10例，計100例である.検 索方法としては Elema-schönander 連続撮影装置を用い 立位，正面，第 1 斜位，第 2 斜位の 3 方向 X線撮影を行 った（写車1).フィルムは秒間 6 枚より2枚まで愁訴の 占居部位別に挿入枚数をかえ，撮影時間は13秒までとし 種々の組合せで最高30枚を限度としてセットした．食道 造影前にまず発泡㓮を投与しバリウムはバレックスモル トあるいはネオバルギン共成硫酸バリウム100〜130\%を 用い，受検者には一口約 $30 \mathrm{ml}$ のバリウムを口内に含ま せ X線技師の合図とともに器下させ撮影を行った．讌下
写真 1

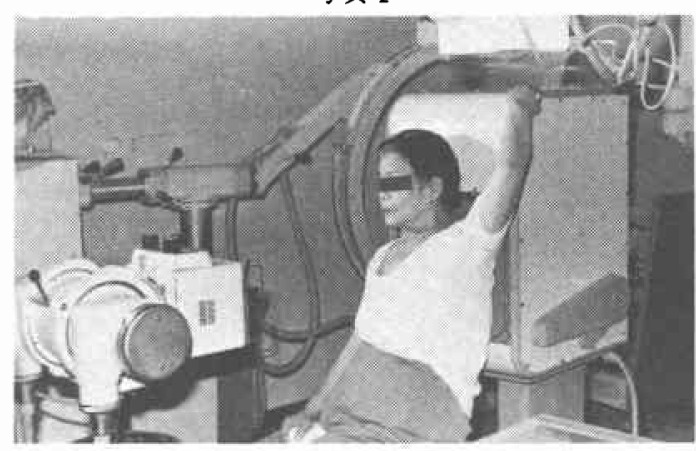

後の空與下は受検者の自由にまかせた。撮影条件は距離 $100 \mathrm{~cm}$, 電圧 $84 \sim 86 \mathrm{KVP}$, 電流 $400 \mathrm{~mA}$,タイマー1/100秒 とした. X線撮影時フィルムの中心点は受検者の愁訴部 かあるいは紹介医によりすでに指摘された食道異常部と したが食道癌取り扱い規約によると Ce 41例，Iu 9例， Im 16例， Ei 24例，CE 10例のごとくである. 連続撮 影後，内視鏡検查执よび生検診断にて明らかとなった訩 断名は食道炎11 例, 食道癌13例，食道噴門接合部癌 8 例 である。これら症例中早期癌は食道および食道噴門接合 部癌の各 1 例に認めたが進行癌では連続撮影はその確認 に留まり,ルーチンには行っていない。

\section{成絯}

1. 症状の内訳と食道所見の有無についてみると（表 3), 絔下困難が57例と最も多いが連続撮影にて異常を 認めないるのが29例と約半数を占めた．以下，食道の異 和感13例中 8 例，心窩部痛 7 例中 2 例に異常を認めなか った．また症状がなく集検あるいは紹介医にて食道異常 とされた10例中 9 例には異常を認めず最終的に連続撮影

表 3 症状の内訳け

\begin{tabular}{|c|c|c|}
\hline & 総 例 数 & $\begin{array}{c}\text { 食道の異常なし } \\
\text { 例 }\end{array}$ \\
\hline 曣下困難 & 57 & 29 \\
\hline 異 和 感 & 13 & 8 \\
\hline 心墖部痛 & 7 & 2 \\
\hline 胸骨後方痛 & 3 & 1 \\
\hline 哭 血 & 2 & 1 \\
\hline 㬭下痛 & 3 & 1 \\
\hline 嗄 声 & 2 & 1 \\
\hline 胸やけ & 1 & \\
\hline 嘔昍 & 1 & \\
\hline 䫓部不快感 & 1 & \\
\hline 燕下障害なし & 10 & 9 \\
\hline 註 & 100 & 52 \\
\hline
\end{tabular}


表 4 䛓下障害の原因

\begin{tabular}{|c|c|c|}
\hline \multirow{2}{*}{ 原 因 } & \multicolumn{2}{|c|}{ 噗下障 害（例数） } \\
\hline & D $\quad 2$ & ts \\
\hline 啔能 的 & 32 & 3 \\
\hline 金道瘦 & $13(1)$ & \\
\hline 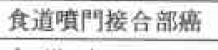 & $8(1)$ & 2 \\
\hline 食道笑 & 11 & \\
\hline 食道意窒 & 6 & \\
\hline 食道裂孔へルニア & 4 & \\
\hline 姐旦石拉 & 2 & \\
\hline 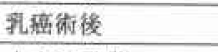 & 2 & \\
\hline 大血管基营 & 2 & 2 \\
\hline 骨による王迫 & 2 & \\
\hline 胃頲歷 & 1 & 1 \\
\hline 食道静䰤変 & 1 & 1 \\
\hline 血 管嚩 & 1 & \\
\hline 基道 Web & 1 & \\
\hline 積部リンハ・腺腫大 & 1 & \\
\hline Lye Stricture & 1 & \\
\hline Mallory-Weiss & 1 & \\
\hline 食道賴髀 & 1 & \\
\hline 噴門部ポリーブ & & 1 \\
\hline 計 & 90 & 10 \\
\hline
\end{tabular}

施行 100 例中52例に食道異常を認めなかった。

2.つぎ食道連続撮影にて判明した臙下障害の原因 についてみると表 4 のごとくである、器下障害がなかっ た10例の内訳は 3 例が機能的, 食道噴門接合部癌 2 例, 大血管異常 2 例, 胃潰瘍, 食道静脈瘤各 1 例, 噴門部ポ リープ1例である.ここでいう機能的とはかりに症状が あっても $\mathrm{x}$ 線的には全く異常の認められないものとし た. 連続撮影施行食道癌 13 例中 1 例に早期癌 st-0 癌（扁 平上皮癌）を，食道噴門接合部癌 8 例中 1 例に早期癌 （腺癌）1例を認めた. 以下，食道炎11例，食道梸室 6 例, 食道裂孔へルニア 4 例, 上部食道 web 1 例があっ た. 以上より食道連続撮影の適応としては一般 $\mathrm{X}$ 線検查 にて粗大病変がないか, もしあっても微細病変の疑いが 強く, しかも德下障害などの主訴を有する症例に限られ るといえよう。

3. 食道連続撮影の部位別, 最適撮影タイミングと撮 影最少必要枚数につき秒間 6 枚撮影のX線像より逆算し えた撮影条件は表 5 のごとくである7゙. 頝部食道のバり ウム通過時間は最る速く（表 2 ), 秒間 6 枚で撮影最適時 間は鯞下開始後 2 秒, 撮影時間は 3 秒間である.この組 合せで䫓部食道に関しては良好な充盈像および嚥下空気
表 5 食道連続撮影方法

(Elema-Schönander)

\begin{tabular}{|c|c|c|c|}
\hline & 秒間枚数 & 撮影時間 (Max) & 最適時間 \\
\hline $\mathrm{Ce}$ & 6 枚 & 3 秒 & 2 秒 \\
\hline Iu & \multirow{3}{*}{3} & \multirow{3}{*}{5} & $1 \sim 3$ \\
\hline$\underline{\operatorname{Im}}$ & & & $3 \sim 5$ \\
\hline $\mathrm{Ei}$ & & & $5 \sim 9$ \\
\hline$\underline{\mathrm{Ea}}$ & \multirow{4}{*}{2} & \multirow{4}{*}{10} & $5 \sim 10$ \\
\hline EC & & & \multirow{3}{*}{$5 \sim 13$} \\
\hline $\mathrm{E}=\mathrm{C}$ & & & \\
\hline CE & & & \\
\hline
\end{tabular}

による二重造影がえられた。胸部食道 Iu, Im, Ei は秒 間 3 枚, 最適時間は Iu で 1 〜秒, Im で $3 \sim 5$ 秒, Ei で 5〜9秒であったが平均撮影時間 5 秒間にてほぼ 満足しらるX線像がえられた．Ea-CE に至る腹部食道 および 食道噴門接合部撮影では秒間 2 枚, 最適時間は 5 〜3秒であったが平均撮影時間10秒間で良好なX線を えた. 撮影は原則として坐位にて第 1 , 第 2 斜位, 正面 の3方にて行った. 以下, 食道連続撮影の実際を症例 にて示す.

\section{症 例}

症例 1 : 連続撮影のタイミングについて.

本例は28歳女性の正常食道で（写萝2）額部より胸部

写真 2

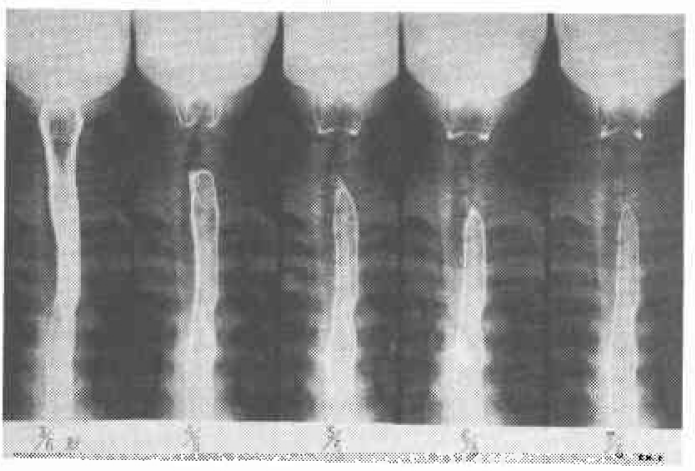

食道連続撮影, 正面, 6 枚/秒（頚部食道～胸部上・ 中部食道)

症例：28才, 㝵, 正常食道. X線像は $130 \%$ バ 的 ム(バレックス・モルト) 使用, 一ロ $30 \mathrm{ml}$ 曣下後の 経時的推移を示すが，3/6 秒にてバリウムは食道の 全長をみたし $4 / 6$ 秒にて第 1 次蠕動波が下降し, 頚 部食道の上半分はすでに読影不能である. 以下順に 蠕動波はゆるやかに下降してゆく４/6 秒以下では 苝下空気による二重造影像がえられている。 
写真 3
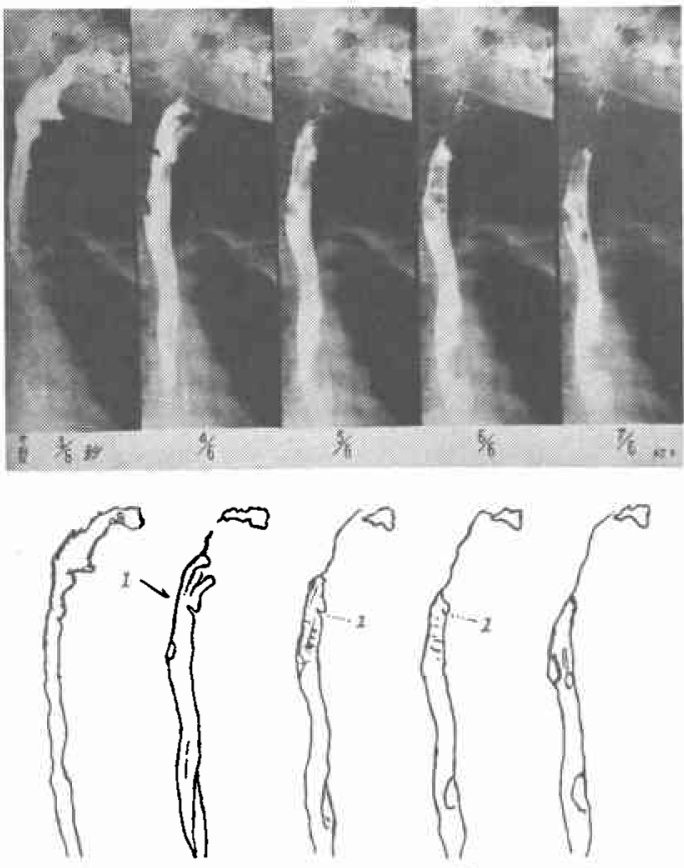

$3 / 675$

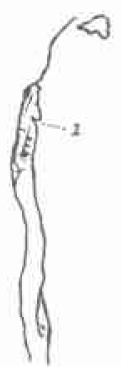

$\$ / 4$

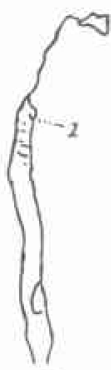

$\%$

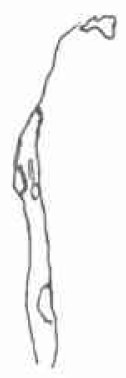

$\% / 6$

食道連続撮影, 6 枚/秒, 頝部食道側面

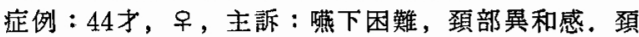
部食道の側面X楾像 $4 / 6$ 秒， $5 / 6 ， 6 / 6$ 秒にて輪 状軟骨下約 $2 \mathrm{~cm}$ 前壁, 約 $1 / 3$ 周にわたる滑らかな 切れ込みを認める．食道壁の硬化像は認めない。 $7 / 6$ 秒ではバリウムは下降しすでに变化を認めない， 診断：上部食道 $\mathrm{Web}$

上中部食道までの連続撮影正面像を示す. 頝部食道のバ リウム通過時間は早く, 下咽頭より $1 / 6$ 秒にて頝部食道 上半部はすでに造影不能になるので頝部食道造影では最 低秒間 6 枚の撮影が必要と思われる.

症例 $2: 44$ 藏女性, 主訴: 嚥下困難および頝部食道の 異和感. 写植 3 は秒間 6 枚撮影第 1 斜位, 預部食道の側 面像を示すが撮影のタイミングのずれにて3/6秒にて燕 下が始まりバリウムは口腔内，下咽頭をみたし4/6秒に て胸部中部食道に達している.4/6秒，5/6秒，6/6秒のX 線像にて胸部上部食道 web が認められるが7/6秒ではす でに所見は認められない。すなわら, 頝部食道造影では 嗌下後 1 秒以内に病変の見逃がされる可能珄の大きいこ とが示唆される。

症例 $3: 78$ 歳男性, 主訴: 食道の 異和感. 真真 41 , 第 1 斜位では胸部上部食道の隆起性病変を, 第 2 斜 位では逆に陥凹珄病変を思わせる所見がある，食道連続

写真 4

(1)

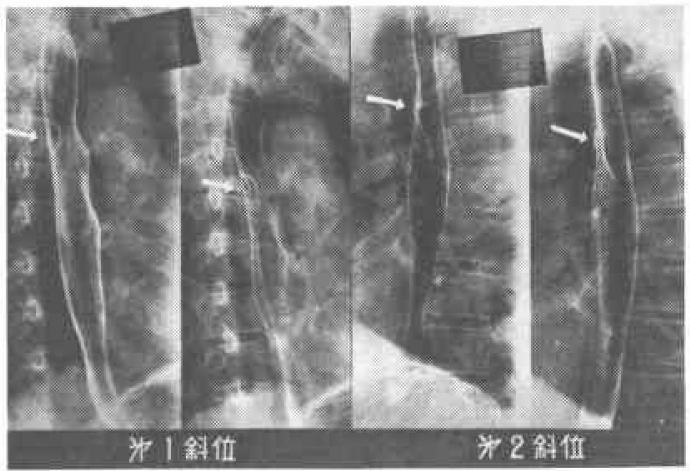

(2)

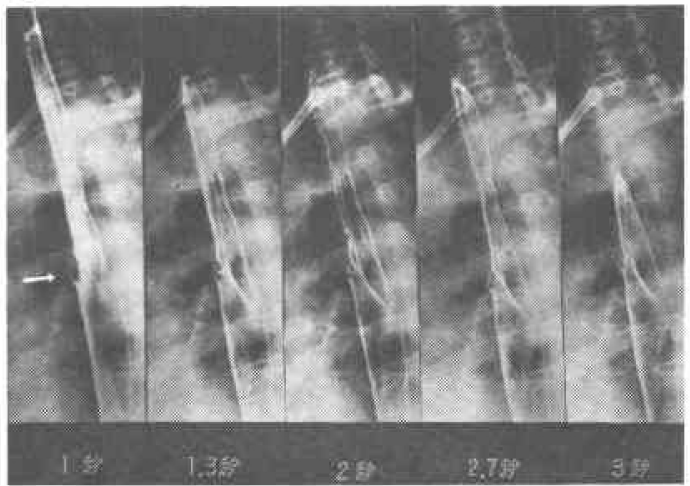

症例：58才方，主訴：食道の異和感。写真(1)の第 1 斜位では胸部上部食道の隆起性病変を, 第 2 斜位で は宿凹性病変を思わせる. 写真(2)の連続撮影ではバ リウム睬下後 1 秒〜 3 秒までの間に食道䡯室の型が 多彩に変化している.

撮影では写车 4-2 のごとく病変部に明らかな食道憩室 を認め第 1 次蠕動波の波及につれ 1 ～秒のX線像のご とく憩室内腔の多彩な変化を認める。

症例 4 : 65歳女性, 主訴：集検による胸部下部食道異 常の指摘. 食道連続撮影秒間 3 枚にて (写真 5 ), バリ ウム鸒下後 $7 / 3$ 秒, $8 / 3$ 秒の充盈像では異常を認めないが 15/3秒以降の二重造影では食道壁硬化像のない陰影欠損 を認め胸部下行大動脈による食道圧迫と診断した。

症例 $5: 69$ 歳女性, 主訴：胸やけ括よび㖟下困難. 食 道造影にて胸部下部食道のらせん型陰影欠損約 $3 \mathrm{~cm}$ を 認め（写齐 6-1）, 食道癌の疑いにて食道連続撮影を行 った・結果は写真およびそのシェーマに示すごとく（写 索 6-2，3）罴下後 2 秒のX線像では漏斗型乃至らせ ん型食道癌の疑いは残るが 3 秒〜10秒までのX線像では 
写真 5

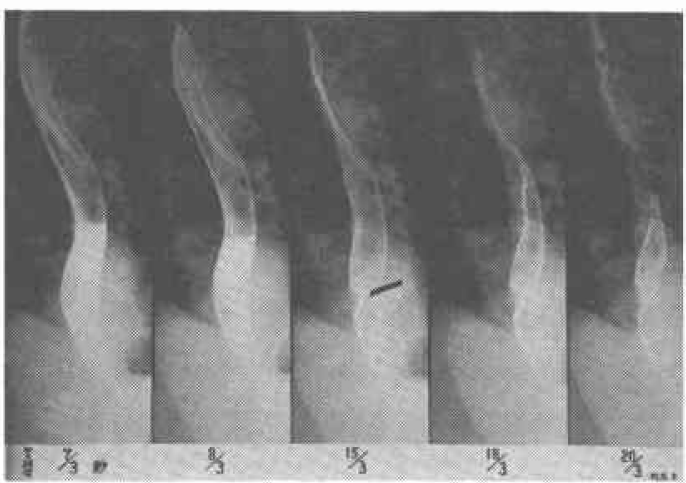

食道連続撮影, 第 2 斜位, 3 枚/秒. 症例：65才, 里. 主訴：食道の集㭘異常. X線像 $7 / 3$ 秒， 8/3 秒は $130 \%$ ・リウム $30 \mathrm{ml}$ 燕下後の充 盈像であるがとくに異常を認めない. 15/3 秒以下 のX線にて二重造影がえられているが食道前壁に缠 瘤型の陰影欠損を認める．食道粘膜レリーフはきれ いで, 食道壁の硬化は認めない。この陰影欠損は胸 部下行動脈による食道圧迫である。
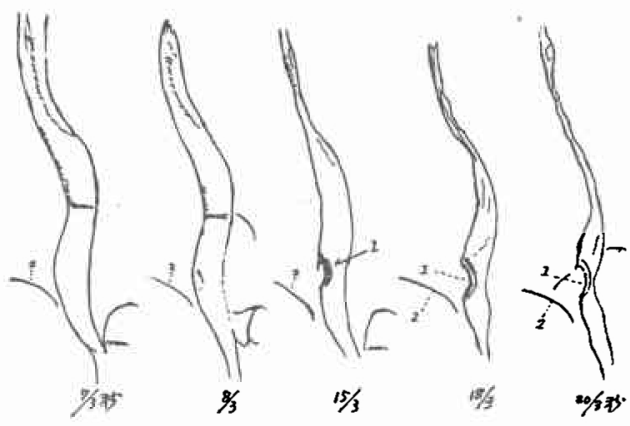

$1 ：$ 大動脈による压迫

2 : 横隔膜

食道潰瘍を伴ら滑脱型食道裂孔へルニアと判明した。食 道噴門接合部で E-G-Junction と思われたものは偽りの ものでへルニア起始部であった.

症例 6：68歳男性, 主訴: 心窝部痛. 本例は18年前, 幽門狭窄の診断にて某医で胃空腸吻合術をうけたが最近 胸部の不快感と心窩部痛を訴兄来院した。胃透視では食 道噴門接合部に隆起性の症変を認め (写真 7-1), 食 道連続撮影では（写真 7-2）8秒以後の二重造影にて 該部に隆起性病変を確認した. 生検では腺癌で早期癌の 診断下に右開胸 - 開腹, 胸部下部食道・噴門部切除, 食 道胃吻合術を行った. 組織学的には sm に留る adenocarcinoma tubulare であった（写真7ー3）.
症例 $7: 70$ 歳男性, 主訴: 鱑下困難. 10年前, 他医に て高位の胃潰韵に対して胃全摘術をうけたが組織学的に は良性といわれた１力月前より靯下困難を訴之来院時 の食道造影は写重 8ー1のごとく狭窄上部（吻合部上 部）の扗張と食道残渣様の停滞を認めた．胸部下部食道 を中心に連続撮影を行らと写真 8 -2 のごとくバリウム 曣下後 3.5 秒〜 8 秒のX線像にて Ei にポリープ状の変 化と浅い陥凹性病変を認めた．連続撮影では2秒にて充 盈像之二重造影を，6秒以降では二重造影がえられてい る. 本症例は右開胸・開腹下に胸部食道部分切除, 胸腔

写真 6

(1)

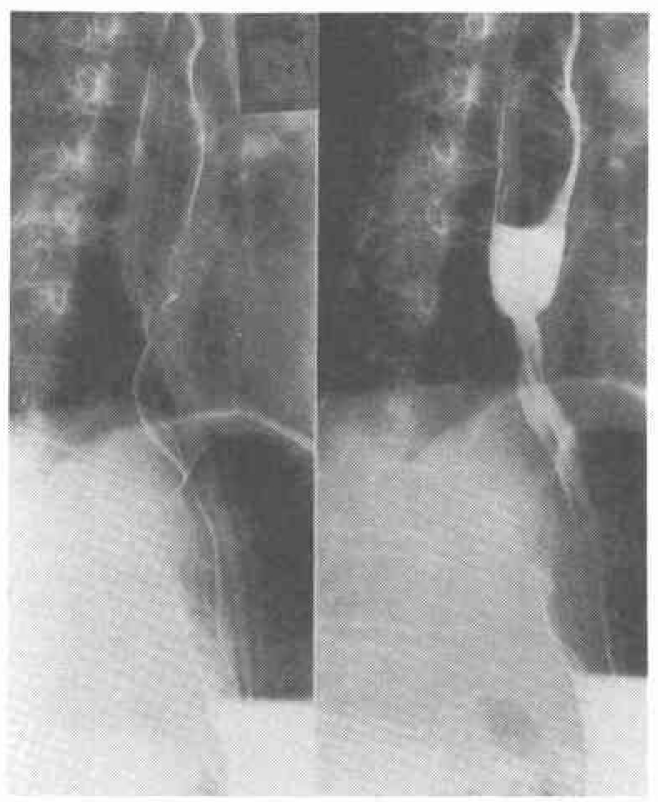
a)二重造影像
第 1 斜位
b) 充盈像

(2)

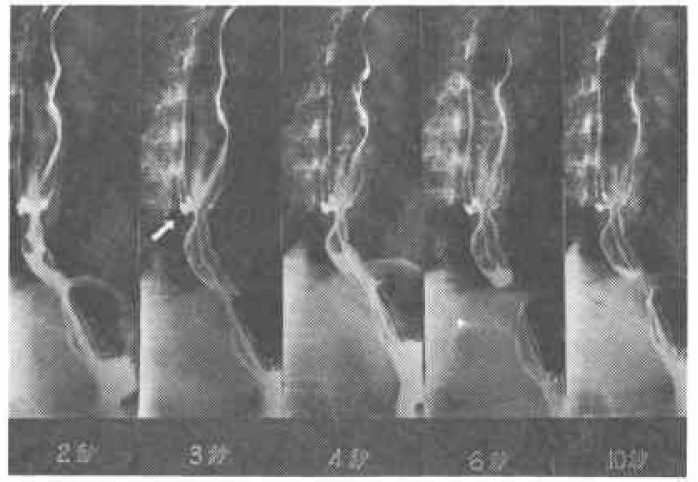


(3)

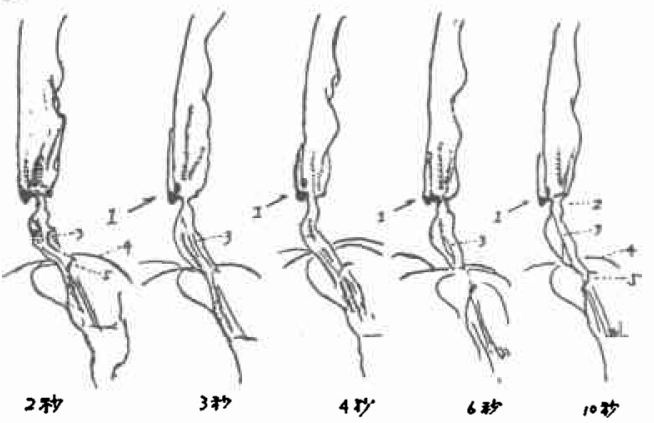

食道連続撮影, 第 1 斜位, 3 枚/秒.

\section{1：食道潰場}

2 : E-G-junction

$3:$ ヘルニア胃・胃粘膜レリーフ

4 : 横隔膜

5 : 偽E-G-junction

: 69才, ㅇ. 主訴：胸やけ, 哭下困難. X線写真(1) は胸部下部食道 $(\mathbf{E i})$ のらせん型の腫瘍陰影欠損を 示す，また食道噴門接合部，E-G-junction は一見横 隔膜下に保たれているよらにみえる，食道連続撮影 ではバリウム暖下後 2 秒では写真(1)と同様漏斗型あ るいはらせん型の腫富陰影を思わせるが，3秒以下， 10秒までのX線像では食道潰瘍（1）食道狭窄が著 明であるが食道壁の硬化像は癌に較べると柔らかく， また横隔膜上部のールニヤ胃内に粘膜レリーフが明 らかで (3), E-G-junction（2)は挙上率引され，(5) が一見偽 E-G-junction と思われたるのである。

診断：滑脱型, 食道裂孔へルニア, 狭窄型, 食道潰 癔合併例。

\section{写真 7}

(1)
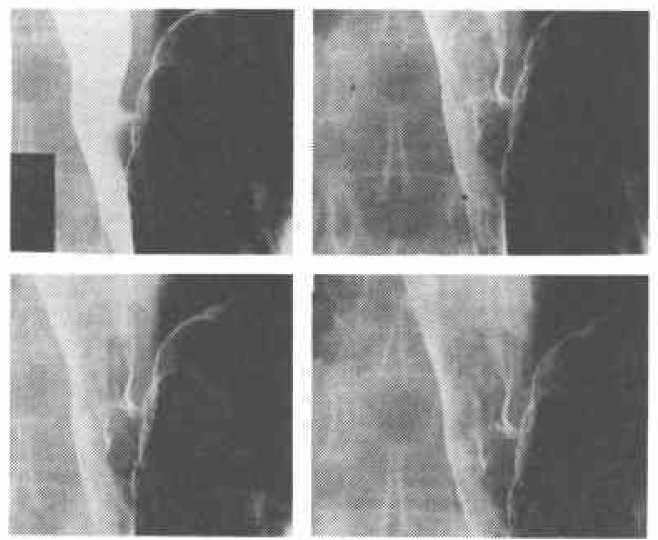

(2)

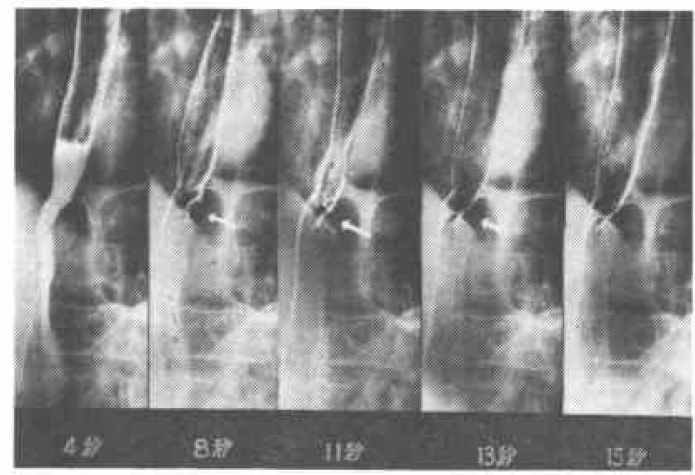

(3)

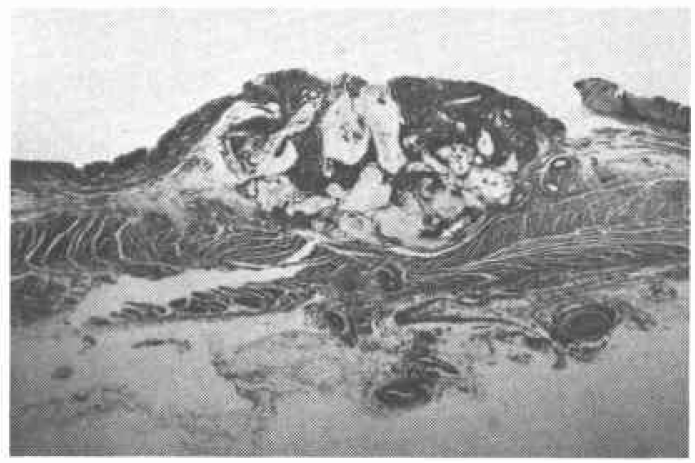

H.E. $20 \times$

食道・噴門接合部に接し, 胃側に粘液産生の著明な

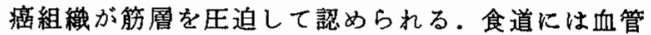
を伴った乳頭の增生と固有層に単核細胞浸潤が認め られる。

写真 8

(1)

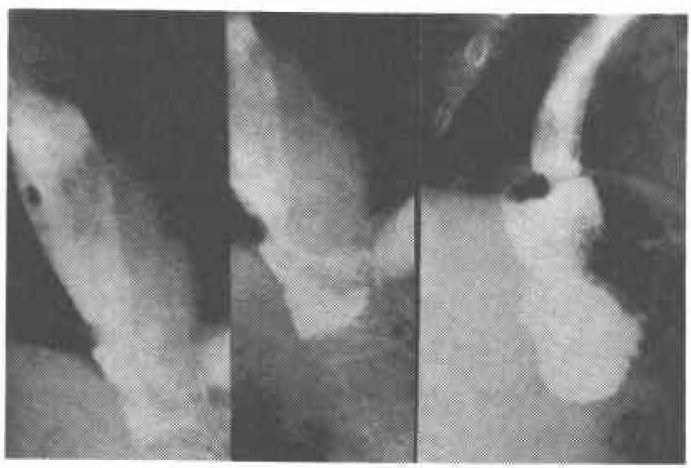


(2)

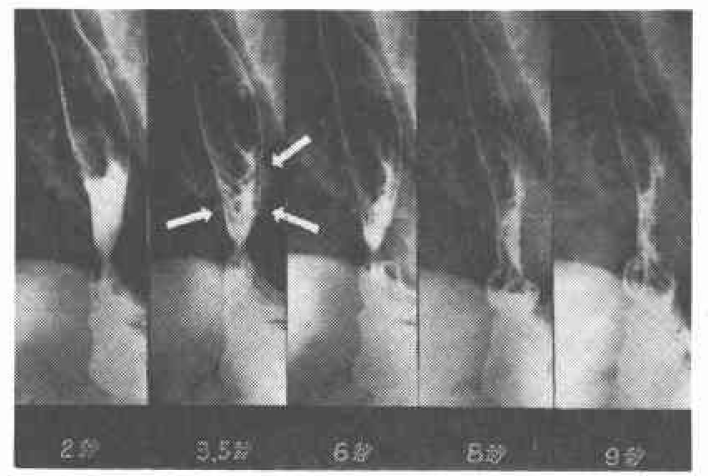

(3)
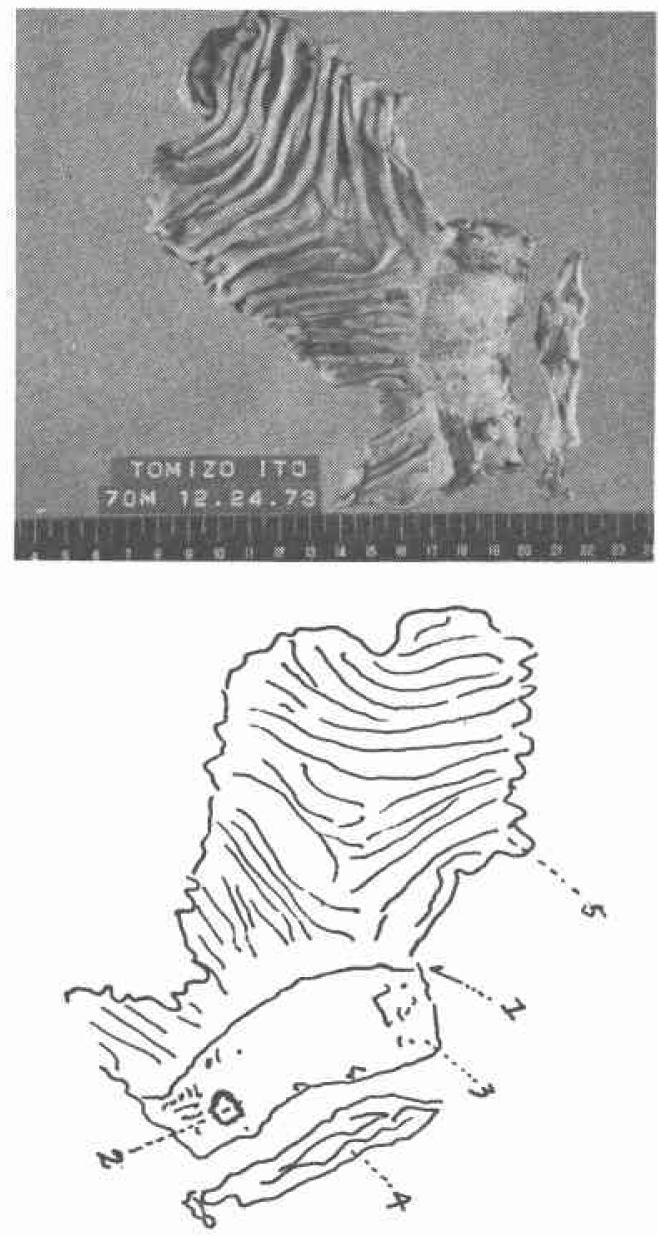

1 : E-G-junction

$3:$ 食道粘膜

5 : 空腸
(4)

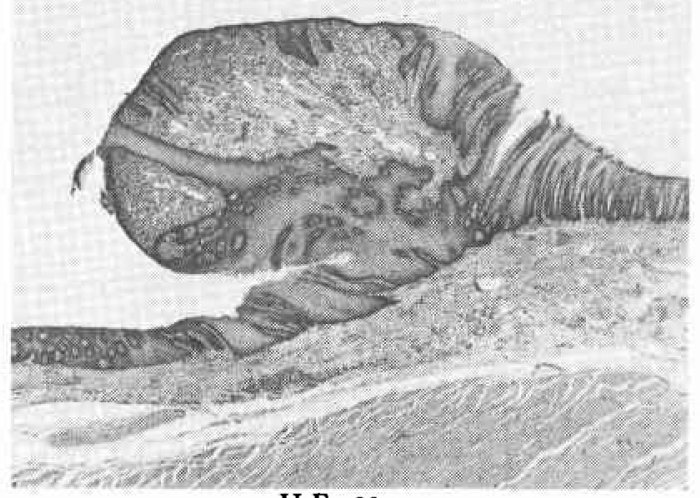

H.E. $20 \times$

(5)

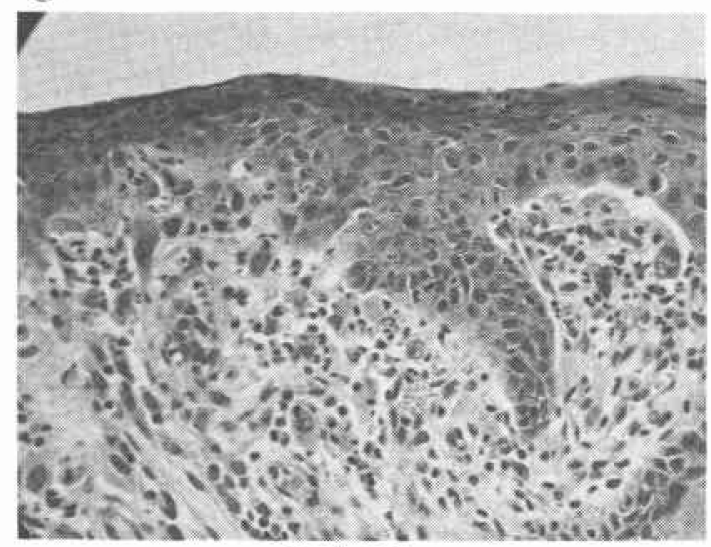

H.E. $350 \times$

隆起性病変の上皮は核小体の大きな染色質の濃い核 をむつた異型性の強い細胞からなり，所々に分裂像 が認められる。これらの異型細胞は粘膜固有層にす たれ状に浸潤している。

内食道空腸吻合術, Roux-Y 法を行った. 肉眼所見は写 枽8ー3のごとくであり組織学的には（写真 8-4, 5 ), 癌はsm に留る扁平上皮癌で stage-0 癌であった. また食道のほ注全周に浅い, erosion を認め, 这流性食道 炎に由来するものが考觉られた。

\section{考察}

食道癌治療成績の向上には早期発見が最も望ましく胃 集検と同様, 現在食道集検等の努力もなされているが, その発見率は早期胃癌の発見率, 全国集計 $0.048 \% \sim 0.0$ $51 \%$ (昭和 49 年, 50 年度) に較べ 15,000 例中 6 例, 0.04 \%との報告8 もあり,かならずしも劣っていないように 思われる.しかしながら早期食道癌報告の実際は1970年 -28例，1974年-58例，1978年-101例 と 毎年 5-10例 
ずつ徐々に増加の傾向にある. 鍋谷の集計にて早期食道 癌の愁訴は燕下障害がなくても哭下時胸痛, 異和感など の初発症状があり, 病悩期間 $2-3$ カ月以内のものも多 く, 病変の壁在性は全周におよび, X線型では表在隆起 型あるいは表在陥凹型が主で，とくに食道二重造影が診 断上重要でありX線検査にて約 $62 \%$ その推定が可能と されている゙2.

$\mathrm{X}$ 線検査による食道病変撮影上の困難珄については表 1, 2 に示したごとく解剖学的に食道は頝部食道が横紋 筋, 胸部下部食道約 $10 \mathrm{~cm}$ が平滑筋, その中間はこれ ら両者の筋層が混在するとされるため", 蠕動抑制剂の 効果は十分期待できず食道造影を困難なるのとしている (表 2 ). また, 食道内バリウムの通過時間の速さが問題 となるがとくに頝部食道のバリウム通過時間は $10.7 \mathrm{~cm} /$ 秒と早く, 該部の診断には写真 2,3 亿示したごとく単 位時間あたりの撮影枚数を增やす以外に適切な対策はな い上らに思われる. 造影剂の食道内通過時間の早さに対 処するためにはX線映画法が最適と思われるが, 撮影, 現像，映画に要する時間的制約がいまだ日常の臨床診断 法としての短所かと思われる. 食道の微細病変診断上, 最も重要とされる食道の二重造影には聴下空気, 胃内空 気の食道内逆流, 経管的空気送入などのうちいずれかに 頼らざるをえない，われわれは今までに胃切除後食道癌 5 例, 胃切除後良性食道狭窄 2 例, 胃全摘後食道癌 1 例 の計 8 例を経験したがこれらの症例はいずれる胃泡が小 さいか，あるいは欠除するため十分な空気の燕下送入あ るいは発泡剤使用の効果が少なく二重造影の撮影が困難 であった。これらの場合には患者を納得の上経管的に十 分, 空気送入を行いよい二重造影写真を撮る心挂けが必 要である。また食道は胃と異なり触診不能の臟器であ るが腹臥位法に枕の使用を追加し, ある程度対処しら る 影は鍋谷の装置 ${ }^{11)}$ と異なり非透視下撮影ではあるが，大 角版フィルム使用下，秒間 6 枚撮影が可能で， $\mathrm{X}$ 線像の 解像力がよく直ちに続影可能な点が有利と思われる.

症例 2 に示した頝部食道 web は組織学的には正常粘 膜あるいは粘膜下層の食道腔内突出であり, 通常外科治 療の対象とされることは少なく内視鏡下切開でむ十分と されている゙．通常 web は䫋部食道の側面 $X$ 線撮影にて はじめて証明可能とされるが実際には頝部食道のバリウ ム通過時間がきわめて早いためその証明は仲々困難であ る.胸部大動脈の圧迫による食道の陰影欠損は大きいる のほどわかりやすいが胸部下部食道の比較的小さい压迫
は一見, 腫瘤型の陰影を示すので食道充盈像と二重造影 像を撮り除外診断することが必要である．高龄者で高血 王・動脈硬化症を有する場合には注意する必要がある。

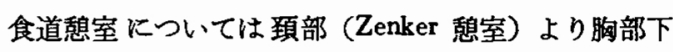
部食道にいたる各部に大小また単発あるいは多発の型で 日常よく遭遇するが慗室炎などの併発症のない限り通 常, 手術適応はない.しかし䕀室内食道癌の報告 ${ }^{12}$ もあ るので長期の追跡が必要と思われる.

随伴性潰瘍の有無に関わらす食道裂孔へルニアの滑脱 型で食道狭窄を来さす頻度は palmer ${ }^{13)}$ によると食道资 を来たした症例の $7 \%$ とされているが，この場合食道癌 との鑑別が重要となる，食道裂孔へルニアに合併する悪 生疾患の頻度は約10\%といわれているので ${ }^{14)}$ ，食道のみ ならす胃内病変の確認に注意する必要がある.

食道噴門接合部領域の早期癌はパリウウムの流れ方，心 搏動の影響をらけることなどよりも診断はなかなかむつ かしい(15)。この境界領域病变の診断の困難性については しばしば，誌上あるいは学会などにても問題とされてい、 るが隆起型の高分化型腺癌の発見頻度に較べ陥凹性病変 の報告はまれである、粕川の集計では ${ }^{16)}$ 全早期胃癌中 $\mathbf{C}$ の早期胃癌は $6 \%$ で, Bormann I 型が多いとしている が，自験例症例 6 は表在隆起型であった. 食道噴門接合 部より上下 $20 \mathrm{~mm}$ 範囲の早期癌は二村 ${ }^{17}$ によると 1975 年 までに 6 例が報告されている.われわれは食道癌自験例 114例中早期食道癌 7 例を経験している. その内訳けは R-st- 0 癌 3 例, st -0 癌 4 例 であるが胃全摘後, 胸部下部 食道に発生した st-0 癌（症例 7）はその1例であり食 道連続撮影にて表在隆起性病変の描写が可能で内視鏡的 にも確認された。これらの胸部下部食道扣よび食道噴門 接合部に発生した早期癌の 2 例に対しては食道連続撮影 は有用であった. Retrospective にみても単発撮りのX 線造影に較べ連続撮影では病変部の把握がより容易であ ク, 熊倉らのいうように ${ }^{15)}$, 第 1 斜位にて噴門部バリウ ムの流れ方の变化をよみ該部の早期病变の診断にあたる には食道連続撮影は極めて有用と思われる。

\section{まとめ}

食道の微細・微小病変の診断にはよいX線二重造影像 を撮ることが大切である、そのためにはバリウムの食道 内通過時間の早さなどに代表される食道造影の特殊性を よく理解し単位時間に可及的多数のX線撮影を行いその X線像を読むことが重要である.X線映画, V.T.R. が今 1つ日常の臨床診断に適用するには制約があるる現在, 1973年来われわれの用いてきた連続撮影装置 (Elema- 
schönander）利用の食道連続撮影は臨床適用があるよう に思われる. 食道連続撮影は食道映画法に代る簡便法と しての検查法に留るとしてる各症例に示したごとく現在 広く普及している本装置使用の食道造影は微細・微小病 変の猃断に役立つので，今後食道および食道噴門接合部 領域病変の精密診断に慗がる方法としてその臨床的意義 と有用性につきのべた。また本法による検查がその早期 発見に有用であった胸部下部食道の stage-0 癌扣よび食 道噴門接合部早期癌の各 1 例についても併せ報告した。

（なお本論文の要旨は第16回食道疾患研究会および第 6 回日本消化器外科学会大会にて発表した。)

おわりに本連続撮影にご協力頂いた平塚市民病院放射 線科技師の各位に深謝する。また貴重な症例を御紹介頂 いた丹羽診療院 (小田原市) 高山欽哉先生 (症例 $6^{18}$ ), 大磯町斎藤内科斉藤正淳先生（症例 7 ）に厚く御礼申し 上げる.

\section{文献}

1) 山田明義ほか：外科がもとめている食道癌の診 断レベル。臨放, $23: 5-13,1978$.

2）鍋谷欣市, 新并裕二: 早期食道癌. 診断と治療, 66 : 223-228, 1978.

3) 瀬木三雄ほか：市郡別・部位別がん死亡(19691971)について. 厚生の指標, $23: 8-49,1976$.

4) 山形敝一ほか：主として細胞診によって診断さ れた早期食道癌の 1 例. 胃と腸， $1: 259-266$, 1966.

5) 中山隆市ほか：食道の早期癌 (stage-O 癌) お よび進行癌（重複癌）の診断における Elema-
Schönander 連続撮影の応用. 日消外会誌, 7 : 636, 1974 .

6）中山隆市和：食道癌の診断における食道連続 撮影法の応用. 日消外会誌, $9: 923,1976$.

7) 中山隆市: 上部消化管造影一食道一その 1 , 臨 床外科, $33: 889-899,1978$.

8）熊谷羲也 : personal communication.

9) Payne, W.S. and Olsen, A.M.: The esophagus Lea \& Febiger, Philadelphia, 1974.

10) Riddervold, H.O. et al.: Abdominal compression; a valuable aid in the examination of the esophagus. Amer. J. Roentgen. 113: 229-232, 1971.

11）鍋谷欣市：食道の X 線連続撮影法. 医事新報, $2653: 125,1975$.

12) Stout, A.P. and Lattes, R.: Tumors of the esophagus. Armed forces Institute of pathology, 1957.

13) Katz, D. and Hoffman, F.: The esophagogastric junction. Excepta Medica, 1971.

14) Vantrappen, G. and Hellemans, J.: Diseases of the esophagus, Springer-Verlag, Berlin, Heidelberg, New York, 1974.

15）熊倉蜸二ほか：X線検査法の進步と展望. 内 科, $37: 964-970,1976$.

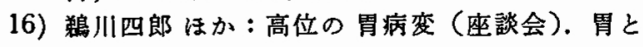
腸, $8: 1120-1128,1970$.

17) 二村雄次汪か：噴門部 squamo-columnar junction の微小早期胃癌の 1 例. 胃と腸, $10: 109$ $113,1975$.

18)藤田峻作, 中山隆市ほか: 喷門部早期胃癌の 2 例. 胃と腸, 11：203-208, 1976. 